\title{
WELFARE STATE CRISIS in TURKEY: AN ASSESSMENT ON THE BASIS of GREEN CARD HEALTH INSURANCE PROGRAM
}

\author{
TÜRKIYY'DE REFAH DEVLETİ KRİZİ: YEŞIL KART UYGULAMASI ÖZELINDE BİR \\ DEĞERLENDİRME
}

\section{Hasan YÜKSEL *}

\begin{abstract}
The main objective of the study is to reveal the dichotomy of being a welfare state or being exploited by civilians on the basis of green card health insurance program shaped by True Path Party and Social Democratic Populist Party and commenced to be implemented in 1992 by $7^{\text {th }}$ Coalition of Demirel Government in Turkey for 30 years. The beginning of 1990s gave birth to a new law numbered 3816 for poor people, the wage of which is below one third of minimum wage income level in a household. This program was sustained by government itself as a mechanism for protecting poor and balancing income; in a way transferring revenue from higher social status to lower ones. It is actually too tough for a state to keep the balance to be social or welfare centered and to be abused. Therefore, the scheme of green card health insurance experienced the same destiny all over the course of the country and it converted into a program through which state could be exploited and which sustained those who were not in need of social care. At the end of 2010, the owner of green card exceeded the number of 10 million in Turkey. In the study, moving from the main parameters of welfare state ideology, the adventure of green card program in Turkey and its end with General Health Insurance (GHI) in 2012 have been demonstrated.
\end{abstract}

Keywords: Welfare State, Green Card, General Health Insurance

\section{$\ddot{O} \mathbf{z}$}

Çalışmanın amacı Türkiye'de DYP ve SHP tarafından şekillendirilen, 7. Demirel Hükümeti Koalisyonunca 1992 yılında uygulamaya başlanan ve 30 yıl boyunca uygulamada kalan yeşil kart özelinde refah devleti olmak ile sömürülmek arasındaki ikilemi açıklamaktır. 1990'lı yılların başları gelir seviyesi düşük, özellikle gelirleri kişi başına asgari ücretin üçte birinden az olanlar için yeni bir yasanın çıkışına zemin hazırlamıştır. Hükümet tarafından desteklenen program yoksulların, muhtaç durumda olanların korunması; gelir adaletinin sağlanması ve gelirin sosyal statüsü yüksek olanlardan düşük olanlara transfer edilmesi anlamında büyük bir öneme sahiptir. Bir devlet için sosyal devlet ya da refah devleti olmak ile sömürülmek arasındaki dengeyi korumak oldukça zordur. O nedenle, yeşil kart uygulaması da ülke genelinde aynı kaderi yaşamış, devletin sömürüldüğü, ihtiyacı olmayanların dahi bu sosyal yardım programından faydalandırıldığı bir programa dönüşmüştür. 2010 yılının sonu itibariyle Türkiye'de yeşil kartlı olanların sayısı 10 milyonu aşmıştır. Çalışmada refah devleti ideolojisinin temel parametrelerinden hareketle Türkiye'nin yeşil kart macerası ve 2012 yılında yapılan yasal düzenleme ile Genel Sağlık Sigortasına (GSS) geçiş ele alınmıştır.

Anahtar Kelimeler: Refah Devleti, Yeşil Kart, Genel Sağlık Sigortası

\footnotetext{
* Asst.Prof.Dr., Çankırı Karatekin University, Faculty of Economics and Administrative Sciences, Department of Labour Economics and Industrial Relations, hasanyuksel37@gmail.com, Çank1r1/TURKEY
} 


\section{Introduction}

In the 1982 Constitution of Turkish Republic, it has been emphasized that Turkish Republic is democratic, secular and social state which can be interpreted that the policies developed by policy makers are to be 'individual' oriented. In social states, individuals are on the center of state mechanism and their welfare, security as well as their peace is of great significance. Instead of market economy and capital accumulation, it is crucial for social states to develop policies that address citizens without exposing them to any sort of discrimination. Therefore, social state, as comprehended from its name, is the type of state which argues universal values for everyone such as "equality", "justice", "security" and so forth. It is to be widely reassessed that welfare state is the new version of social state from a different perspective; particularly in western countries. Thus, the arguments all over the course of the study are based on the term of welfare state carried out local and national unities in a country or a state (Çolak and Özer, 2015: 116).

As stated well before, one of the main peculiarities of welfare state is "security" which is quite different from the word used in international relations or law-enforcement officers' terminology. Here, what is meant through the word "security" is the social security itself which can be defined as a system that "provides income transfers from active workers to those over age sixty-five" (Diamond, Lindeman, and Young, 1996: 26). However, social security is not solely a transferring mechanism for old age pensioners; rather it is more than that (Social Security Administration, n.d: 5). It is the name of the system that protects everyone against the economic outcomes of some possible social risks like diseases, occupational diseases, job accidents, disability, aging, and death which are liable to emerge in the future; thus, it guarantees not only today but future as well. Social security systems work via the premiums collected from social insurant depending upon their wages. According to Third Chapter of Turkish Constitution named after "Social Right and Responsibilities", Everybody has the right for social security." (Turkish Constitution, Article 60). As seen in the Constitution, social security is the "right" for every Turkish citizen and it is a responsibility for the state to provide these services; to put in another way, Turkish citizen has the right to demand social security services while the state is to suggest them.

Turkish social security system is based upon compulsory social insurance program (premium oriented regime) the fundamental framework of which is shaped through the premiums paid by insurance holders (Güzel, Okur, and Caniklioğlu, 2010: 721-724; Tuncay and Ekmekçi, 2013: 132-137). In addition to social insurance program, Turkish social security system has the regime free from premiums. In this regime, the outgoes of system are met by financial transfers from state budget which is a "must" for the state on account of the fact that mandatory social insurance program did not include some groups of people such as "poor" and "unemployed". They had no financial power to support their health expenditures themselves. Hence, in 1992, the political parties forming the coalition government which consisted of two parties; DYP and SHP suggested a new program called "Green Card" which was financed through taxes and which could be included in the premium free system. This program was the new product of populist manifesto of coalition government. Since 1992, the number of Green Card Holders has increased and it has reached \%13 of the total population (Karadeniz, 2012: 104). In 2010, the number of Green Card holders has raised to 10 million which revealed the fact that the Green Card Health Insurance program has been exploited and those who are not needy possess Green Cards and the system was regulated and revised again in 2012 on which the Law of General Health Insurance Program was passed.

The purpose of the study is to reveal the dichotomy of being a social state or being exploited by civilians on the basis of green card health insurance program shaped by True 
Path Party and Social Democratic Populist Party and commenced to be implemented in 1992 by $7^{\text {th }}$ Coalition of Demirel Government in Turkey for 30 years. The study consists of three chapters. In the first Chapter of the study, moving from the definition of social state, the main paradigms of social state were revealed. In the second Chapter of the study, the implementation of Green Card and its features were ascertained. As for the last part of the study, the data set concerning Green Card Holders was given.

\section{Welfare State: A Phenomena or A Legend}

Roosevelt government in USA initiated a new program called as New Deal to minimize the adverse effects of Great Depression in 1936 on which the idea of new social security laws were passed and welfare state came to the fore that aimed to the intervention of government to the market economy. In liberal economy, markets were left to the initiatives of "capital" rather than individual and it resulted in a big catastrophe in 1929. Thousands of people became unemployed and a great many people committed a crime. In the aftermath of Great Depression in 1929, new laws concerning the social provision and social care came to the agenda of USA and within the framework of New Deal regulations, social insurance system commenced with the occurrence of new social security laws. And after that, Beveridge report was published in 1942 which ascertained the main framework of social risks and envisaged the universalist welfare state that suggested the facility of detailed insurance system. In this system, social services offered are not in compatible with the monetary contributions based on premiums, which is the main feature that differentiates social insurance from private ones (Risa, 1995: 129).

Welfare state is the sort of the state that "provides an invaluable point of reference for locating the issues raised by contemporary struggles over the state's role as an agency of social amelioration" (Person and Castles, 2006: 1). Today, providing welfare to everyone from all spheres of life is one of the ultimate concern of states which entails the fact that the state spend much more on welfare than on other purposes. So, the welfare plays a very crucial role for sustaining peace in the society (Person and Castles, 2006: 1). As seen in the following table, there are different definitions of welfare state in the literature.

Table 1. Connotations of Welfare State

\begin{tabular}{l|c}
\hline Definition & Source \\
\hline $\begin{array}{l}\text { "The welfare state is part of the very } \\
\text { core of social democracy. It ensures that } \\
\text { basic rights are not merely formal, but can } \\
\text { be actively realized." }\end{array}$ & (Dahm, 2012: 8). \\
\hline "A social system in which a & (http://www.merriam- \\
government is responsible for the economic \\
and social welfare of its citizens and has \\
policies to provide free health care, money \\
for people without jobs, etc.; also: a country \\
that has such a system" \\
\hline $\begin{array}{l}\text { Welfare state analyses depend upon } 25 \\
\text { parameters such as political }\end{array}$ \\
$\begin{array}{l}\text { somenary/welfare\% } \\
\text { institutions, demographic composition, and } \\
\text { macroeconomic factors and globalization } \\
\text { process. }\end{array}$ \\
\hline
\end{tabular}




\begin{tabular}{l} 
Welfare state is the type of ideology \\
that overtakes economic burdens and \\
surpasses the limits of economy for the \\
wellbeing of their citizens. \\
"Analyses of the social bases for \\
support of the welfare state include three \\
approaches. The first emphasizes 'class \\
politics' and the lasting influence of \\
political coalitions formed at critical \\
historical periods. The second highlights the \\
influence of self-interested rational actors, \\
especially the participation by the middle \\
classes in the welfare state. The third is \\
concerned about the influence of 'transfer \\
classes', especially of groups (like age \\
pensioners or the unemployed or single \\
mothers) who are directly dependent on the \\
welfare state than others." \\
\hline Welfare states provide equal \\
opportunity for people concerning services \\
suggested like education, health, and so on.
\end{tabular}

Rather than the hegemony of a particular group of people, the ultimate concern of welfare state is to settle "equality' in all the spheres of life which means that "class politics" is of great significance. The second point that welfare state highlights is the enforcement of middle class, and the last one that welfare state strives to capture the attention is the dominance of 'transfer', in other words the redistributive function of social security funds for those who are age pensioners, unemployed, single mothers or poor (Papadakis, 1993: 249). This sort of vision is actually the general perspective of Goodin (1985), "that adumbrates the notion that responsibility to provide for "needy strangers" flow from the same source as family "responsibility". That is to say, protecting the nation as a whole without any discrimination comes from the emotional aspect of mother or father to keep all the family members safe and secure. It is a challenge but responsibility for parent to shield and care for their children, so is the state itself (Defending the Welfare State, 1986: 949; Goodin, 1985: 775-787).

Division of labour as well as citizenship discourses and ideologies femininity or masculinity leave a great impact on the character of welfare states, the main peculiarity of which is shaped through social provision, social assistance and social insurance programs (Orloff, 1996: 51). Social spending of the budget and the residents centered policies strengthen the efficacy of welfare state notion. Where there is wellbeing of a nation, there is a welfare state which is sometimes exposed to criticism on account of the fact that it enforces its economic limits (Alber, 1988: 181). This can be interpreted in a way that welfare state is skeptical about regarding economy or society. Which one is true? That is the question. If welfare state notion takes into account economy rather than society, then the rights of social groups can be ignored; while it gives priority to society, the discussions on the basis of 'economic crisis' are liable to emerge. Actually, preferring the convenient instrument for the activation of social policies and social assistance is critical for welfare state identity. 
Figure 1. The Instruments of Welfare State

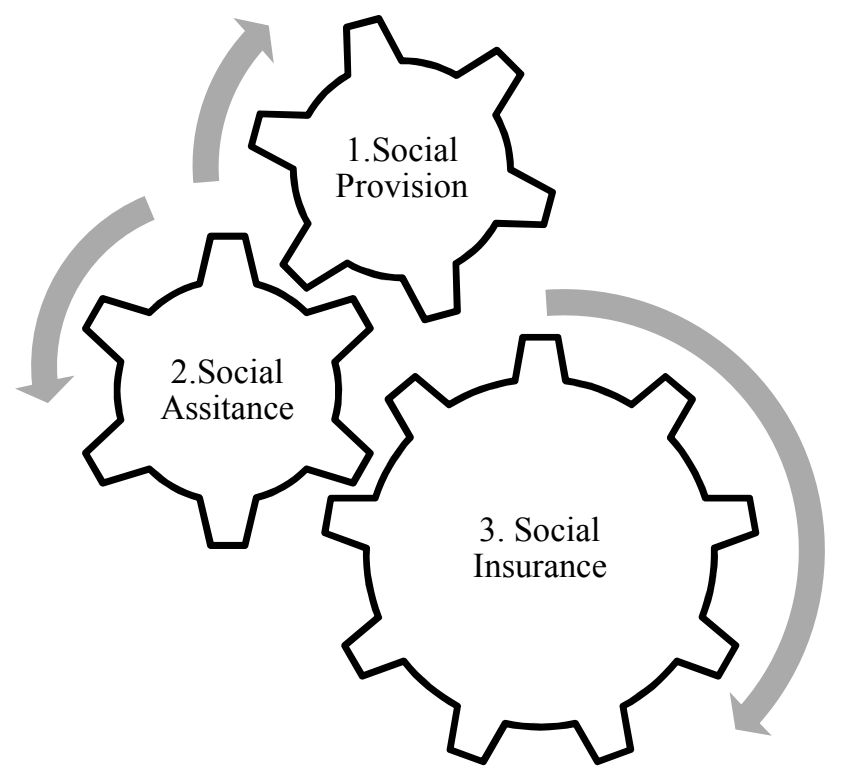

Source: (Orloff, 1996: 51)

Under normal circumstances, welfare state policies yield useful consequences on the reduction of poverty, street crimes additionally, contribute to better neighbourhood, health standards among various income groups, accumulation and the distribution of the capital, and high labour force participation (Lindback, 1995: 9). T.H. Marshall indicated that (1964 as cited by Hasenfeld and Rafferty, 1989: 1029) welfare state was born as a result of the civilization of social system as in the following (Hasenfeld and Rafferty, 1989: 1029):

"The ideological justification for the modern welfare state emerged from the extension of citizenship rights to include social rights, namely the right to an acceptable level of economic welfare and security, and to live the life of a civilized being according to prevailing social standards. Hence, there is a close association between the endorsement of these rights and support for welfare state programs. We hypothesize that individuals who endorse social rights (i.e, government guarantee of economic security) are more likely to support welfare state programs."

Dalmer Hoskins, Secretary General of the International Social Security Association, stated that welfare state is a determinant factor concerning covering social risks and it is a line that demonstrates the role of the state about protecting individuals and where to start and where to end (Hoskins, 1998: 1-9; Gilbert, 2004: 19). This is quite challenging for the welfare states to arrange the level and the volume of the protection. Mau and Veghte (2007) assure that welfare state as a sort of activities that "can be understood as piggy bank redistribution assisting individuals to redistribute income over their life cycle and to limit income volatility, other parts as Robin Hood redistributions shifting resources from the top of the inequality hierarchy to the bottom." (Mau and Veghte, 2007: 2). As recalled, Robin Hood occurred in the atmosphere of exploitations of the civil rights when state withdrew from social life and its regulation. Robin Hood took from the rich and gave to the poor, and he tried to social equilibrium all over the course of the society. The emergence of welfare state was not strikingly different from this case. Welfare state dominance is actually government intervention to the social and economic system so that "equality" can be settled on a sound basis (Andrew, 1984: 668). 
Labours' notion about welfare state is a little bit complex. Some take into account welfare state as a "weapon" through which the power of struggle against capital is undermined while others are on the point of view that welfare state eases capitalist exploitation. Therefore, in recent years, the relationship of labour to the welfare state has become problematic (Garton and McCallum, 1996: 116).

New trends in labour markets as well as the process of globalization endangered the existence of welfare state and strong debates began in the mid-1980s concerning both moral and economic decline of welfare state investment (Gilbert, 2004: 11; Freeman, Topel, and Swedenborg, 1997; Brady, 2005: 1329; Oorscot, Opielka, and Pfau-Effinger, 2008: 5). Globalization gave birth to competition and it increased the burden on the welfare states. To put in another way, globalization paves the way to the welfare state reduction due to international competition in line with the flexible labor force. In other words, the states were to make a choice about whether they were welfare state or the state of competition. In this atmosphere, the ideology of welfare state began to be questioned (Brady, Seeleib-Kaiser, and Beckfield, 2005: 923; Corpi, 2003: 589). The retrenchment in the welfare state spending and their results is indicated as in the following (Huber and Stephens, 2001: 1, 2):

"In our analysis of the crisis of the welfare state in the last two decades, we found that retrenchment was pervasive: Almost all advanced industrial democracies cut entitlements in some programs in this period. [...] We found that the immediate cause of welfare state retrenchment was a large and apparently permanent increase in unemployment. With more people dependent on welfare state, budget deficits ballooned and governments moved to control and then reduce deficits by cutting entitlements. In this era, the effects of the political colouring of governments declined substantially as conservative governments were reluctant to cut popular welfare state programs and leftist governments found it difficult to raise taxes in times of economic difficulty."

\section{The Case of Green Card Health Insurance Program}

Green Card Health Insurance program was brought to the agenda by DYP and SHP government to be implemented in 1992 by $7^{\text {th }}$ Coalition of Demirel Government in Turkey for 30 years. The beginning of 1990s gave birth to a new law numbered 3816 for poor people, the wage of which is below one third of minimum wage income level in a household. This law prepared the infrastructure of Green Card Health Insurance Program, so it was named as the "Law on the Poor Civilians' Expenditures on Health Supported by the State by Giving Green Card" (Orhaner, 2006: 13). This program was sustained by government itself as a mechanism for protecting poor and balancing income; in a way transferring revenue from higher social status to lower ones. Therefore, the scheme of green card health insurance experienced the same destiny all over the course of the country and it converted into a program through which state could be exploited and which sustained those who were not in need of social care. At the end of 2010, the owner of green card exceeded the number of 10 million in Turkey. With General Health Insurance that came into effect in 1.10.2012, the coverage of the healthcare services enlarged as well and the segmented structure of the social insurance program converted into the one that included unity (Tatar and et al. 2011: 1-186; Karadeniz, 2009, available at http://socialprotection.eu/files/353/asisp_ANR09_Turkey.pdf, 15 January 2016; Karadeniz, 2012: 104).

Turkish social security system can be categorized into "compulsory" and "voluntary" depending upon the coverage of the system. As an example, compulsory system includes 
those who are "employed", "self-employed" or "civil servants" whereas the voluntary system serve for those who work in agriculture and who have no social security (Karadeniz, 2007, available at http://www.issa.int/pdf/warsaw07/2karadeniz.pdf, 15 January 2016). On the other hand, those who work as unpaid family workers, students not participating labour markets, and unemployed were excluded from social security system (Karadeniz, 2012: 105). Therefore, those who were out of social security system and who did not take any wage because of their work, and whose wage was below one third of minimum wage income level in a household could get benefit from social security only through Green Card (Law No: 3816). Green Card system had provided a large and comprehensive social protection particularly for poor for 30 years and the number of beneficiaries had enhanced to 10 million and their costs to social security system became 1.493.027 TL in 2010 (http://www.sgk.gov.tr/wps/portal/tr/kurumsal/istatistikler/sgk_istatistik_yilliklari, 29 December 2015).

\section{Graphic 1. Total Costs of Green Card Holders to Social Security System Based} Upon Account of Invoice

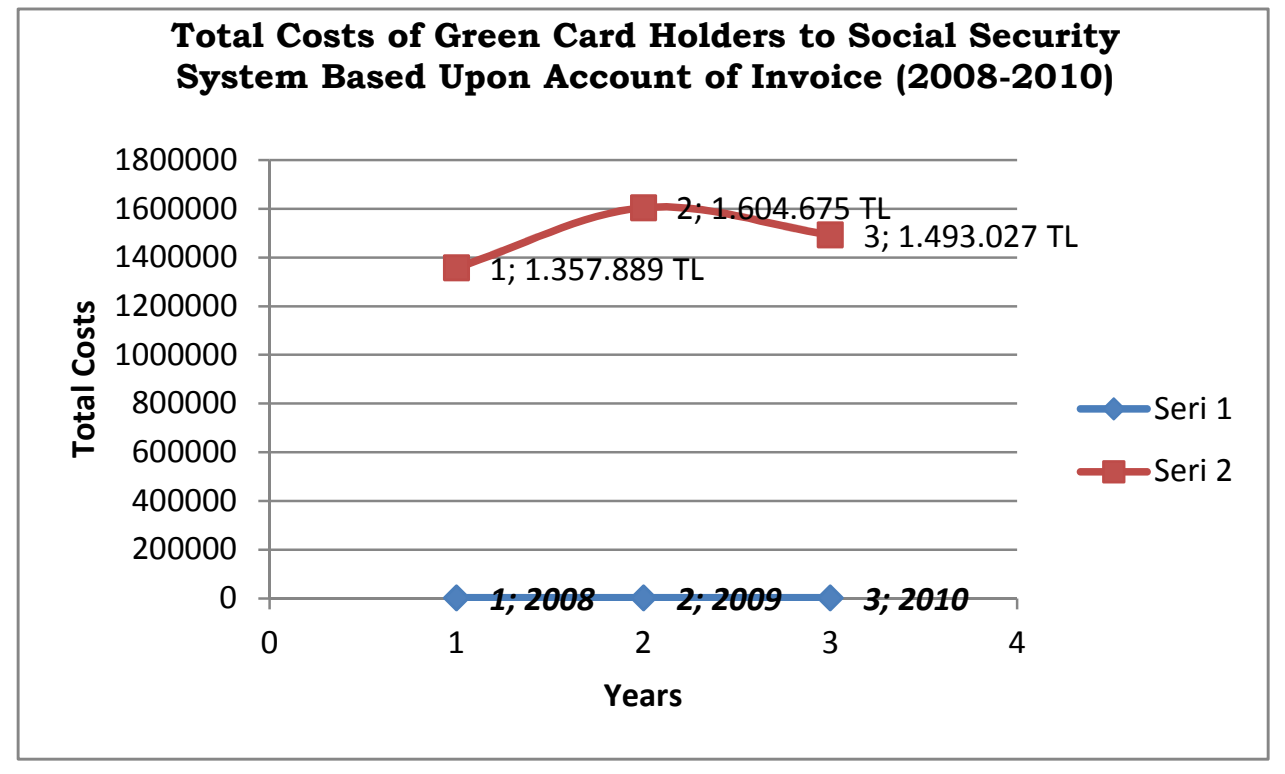

Source: Adapted from SSI statistics, available at

http://www.sgk.gov.tr/wps/portal/tr/kurumsal/istatistikler/sgk_istatistik_yilliklari (29 December 2015).

Total costs of green card holders to social security system based upon account of invoice increased from 1.357.889 TL to 1.493 .027 in spite of fluctuations. In 2009, it reached the highest point and the amount was 1.604.675 TL out of 16.005.392 TL in total public social security expenditures. The rises in the amount of the Green Card Holders to social security system constituted a risk for the perpetuity and sustainability of the system. This green fact also revealed the idea that green card system emerged as a "shield" in particular for poor initiated to be exploited by those who are not need indeed. This table stemmed in an obligation about questioning the existence as well as regulation of the system from the beginning. Thus, the beneficiaries of General Health Insurance including former Green Card Holders were exposed to mandatory income test by means of the new law that came into effect in 2012 (Graphic 1). 


\section{Green Card, Its Content, and Conditions for Beneficiary}

Green card health insurance program started with the Law numbered 3816. The fundamental goal of the Law is to settle and expand social security coverage for those who are out of social security programs. It covers the social security services as well as the outgoes of those whose wage is below one third of minimum wage income level in a household and those who accommodate in Turkey. Those who do not meet these criteria cannot benefit from the program (Law No: 3816, article: 3). The services suggested from the program include (Law No: 3816, article: 2):

a) Their expenses of the inpatient treatment in Turkey,

b) Their expenses within the framework of ambulatory treatment such as "treatment, examine, medical analysis, medical dressing, exodontic treatment, dental prosthesis, glass services and drug expenses in health institutions in Turkey,

c) On condition that ninety days are not exceeded, the new born baby of mother and father who are green card holders and his/her expenses concerning emergency medical intervention, treatment expenses of mother in the hospital where she give birth or in the hospitals to where they are incited and their inpatient and ambulatory treatment expenses,

d) On condition that ninety days are not exceeded, the expense of the patients in the hospital due to emergency medical intervention and treatment till green card is obtained,

e) Institutions that give medical treatment.

It is witnessed that the implementation of green card covers all medical expenses of poor which settle and sustain a social balance in the society and which offer the facility for redistribution of income from higher status to the lower one. This program is also a chance for the settlement of welfare state which argues the idea that the state is to take over a role on intervention to the economic infrastructure. By means of this program, the poor is not left alone so as to struggle against poverty. However, conditions for being a beneficiary of this program depend upon some certain criteria (https://www.ttb.org.tr/mevzuat/index, 30 December 2015; Tarcan and Şahin, 2000: 70, 71; Kaya and Bozkurt, 2011: 134, 135).:

Determination of monthly wage is carried out depending upon the wages of husband, mother, father, or third degree relatives living in the same house (Law No: 3816, article 4).

To calculate the household wage of each person (Law No: 3816, article 4)

a) Income such as wage or daily wage for services given,

b) Total monetary income of agriculture,

c) Income of movable or real estate rent, interest and dividends

d) Monetary transfer and grant income obtained from state, private initiatives or other people or institutions,

e) Income in kind is also taken into account.

Total monetary income and income in kind of household obtained depending upon the article above is divided into the number of people living in the same house in order to ascertain whether it is below the amount indicated in the article 2 (Law No: 3816, article 4).

Based upon the procedure and principle of this Law (Law No: 3816), the demands to obtain "Green Card" of those who would like to be beneficiary are assessed by board of provincial or district administration (Law No: 3816: article 6). Just as they are carrying out their duty, these boards established in provinces or districts have the right to get required information and documents concerning demandants and they can organize meetings which 
mukhtar participate in. Mukhtars, ${ }^{1}$ police officers and gendarmes have also the right to investigate the economic status of demandants which is quite significant so as to determine the right person as a Green Card Holder (Law No: 3816: article 7). In the aftermath of detailed investigation and analysis, Green Card is given by governorate and district governorate on the basis of provincial or district administration decisions (Law No: 3816: article 8). For Green Card Holders, health services offered are free of charge owing to the fact that health institutions send bills to the Ministry of Health which recompenses the expenses (Law No: 3816: article 9).

\section{The Methodology of the Research}

The aim of the study is to put forward that social security implementations that come into effect in line with the ideology of the state concerning social policy in overall are open to exploitation providing that necessary precautions are not taken. This is also the case for Green Card Implementations. Hence, in the study the data collected from various sources including Ministry of Work and Social Security, Ministry of Health, Social Security Institution, TURKSTAT, and some certain institutional reports have been analyzed, which enable to portray the snapshot of the Green Card system.

\section{The Data of the Research}

The data of the research was gathered from different sources particularly from public institutions such as Ministry of Work and Social Security, Ministry of Health, Social Security Institution, TURKSTAT, and so on. The collected data were analyzed within the perspective of Green Card Implementation, its ups and downs especially taking into account beneficiaries who are not needy indeed.

\section{Findings and Results}

The research conducted by Economic and Social Research Center (BETAM) in 2009 reference the profile of Green Card Users. According to research, Green Card Holders are those whose level of education is too low or who are uneducated, that is to say illiterate. Green Card Holders, as their income and wage are too little, reflect the features of classical Turkish family and the great majority of them work unregistered which can be interpreted that most of them do not have any social security (Gürsel, Darbaz, and Karakoç, 2009: 2).

\footnotetext{
${ }^{1}$ In Turkish political system, they are the village headman that runs the village. Their political status is based upon election and they work as 4/I-b which is a sort of social insurance type. General social security system of Turkish social security coverage is oriented on social insurance and social assistance. Social insurance system is called as premium oriented, in which premiums are accumulated compulsory within the framework of Law No: 5510, article 79 (The Law of Social Insurance and General Health Insurance) while social assistance is free from premiums. In the premium oriented program, employees work according to three insurance categories such as 4/I-a, 4/I-b, and 4/I-c. The first one covers those who work in private sector as employee in exchange for service contract (i.e trade union managers, commercial car drivers, employees of embassy and consulate, foreigners and refugees, artist and authors) while 4/I-b regulates social insurance for those who are self-employed (i.e taxpayers, jockeys, and mukhtars). Those who work as civil servants have insurance within the category of 4/I-c (i.e president, prime minister, member of parliaments, mayors). As for social assistance in social security systems, it is utilized to support the needy without getting premiums and it is a kind of apparatus that switches the door of welfare state on. Green Card Health Insurance program was also promoted within the framework of social assistance in 1992. Additionally, orphanage (Law No: 2828, date: 1983), the old who are needy and their 65 years of age salary on the basis of poverty test (Law No: 2022, date: 1976), Foundations of Social Help and Social Solidarity (Law No: 3294, date: 1986) are organized within the social assistance program (Yüksel, 2014: 99-102; Aky1ld1z, 2012: 17-345; Alper, 2014: 81-139,315-342).
} 
Table 2. The Profile of Green Card Holders

\begin{tabular}{c|c} 
Education & $\begin{array}{r}\% 90 \text { of Green Card Holders who are over } 15 \text { years old } \\
\text { has primary school education. Some of them do not. }\end{array}$ \\
\hline Type of Family & $\begin{array}{c}\% 76,7 \text { of Green Card Holders have three children and } \\
\text { they live in patriarchal and large family. }\end{array}$ \\
\hline Employment & $\begin{array}{c}\% 50 \text { percent of } 15 \text { (+) years old of Green Card Holders } \\
\text { are employed. }\end{array}$ \\
\hline $\begin{array}{c}\text { The Size of } \\
\text { Workplace }\end{array}$ & $\begin{array}{c}\% 79,7 \text { of Green Card Holders employed work small in } \\
\text { busines where } 1-9 \text { worker is able to work. }\end{array}$ \\
\hline Home & $\begin{array}{c}\% 74,6 \text { percent of Green Card Holders who live in urban } \\
\text { areas possess home ownership. }\end{array}$ \\
\hline Heating & $\begin{array}{c}\% 96,3 \text { of Green Card Holders who live in urban areas } \\
\text { reside in houses heated with stove. }\end{array}$ \\
\hline Car Ownership & $\% 96,7$ of Green Card Holders do not have cars.
\end{tabular}

Source: (Gürsel, Darbaz, and Karakoç, 2009: 2).

Table 2 gives the idea that the educational profile of green card holders is too low which means that the great majority of them are unqualified. This green fact brings about two results: unemployment or employment with low wage. As for the type of the family, green card holders are the reflectors of Turkish tradition due to the fact that $\% 76,7$ of them live in patriarchal and large family instead of nuclear family. \%79.7 of green card holders are employed in small businesses. At the same time, the great majority of green card holders possess home ownership while $\% 96.7$ of them do not have any cars. The reason is that homes are much more significant than cars for most of the village rooted families because they are the symbol of "guaranteeing yourself". However, cars mean extra outgoes for lower class families (Table 2).

Graphic 2. The Type of Payment of Health Care Costs By Sex (2012)

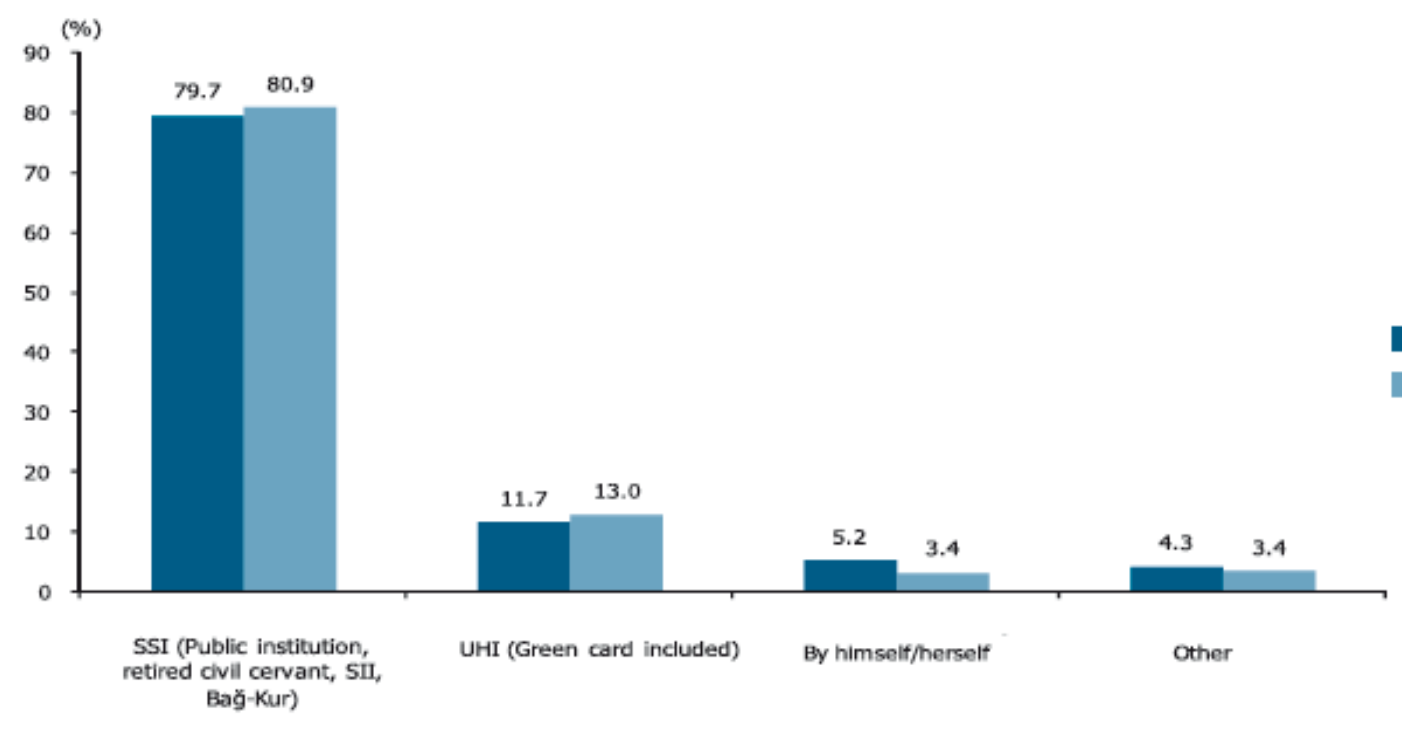

Source: TURKSTAT, Health Survey, 2012. 
In Turkey, depending upon the type of the health care costs survey carried out by TURKSTAT in $2012, \% 80.9$ of females were included within the framework of social security insurance while $\% 79.7$ of males were taken into account in this category. Females constitute the biggest scale concerning green card possession (\%13.0). On the other hand, $\% 11.7$ of males meets health care costs by utilizing green card. Those who pay health care costs by himself/herself are very little (\%5.2 for male; \%3.4 for female) (Graphic 2).

\section{Groups $^{2}$}

Graphic 3. Distribution of Health Insurance Beneficiaries in Different Income

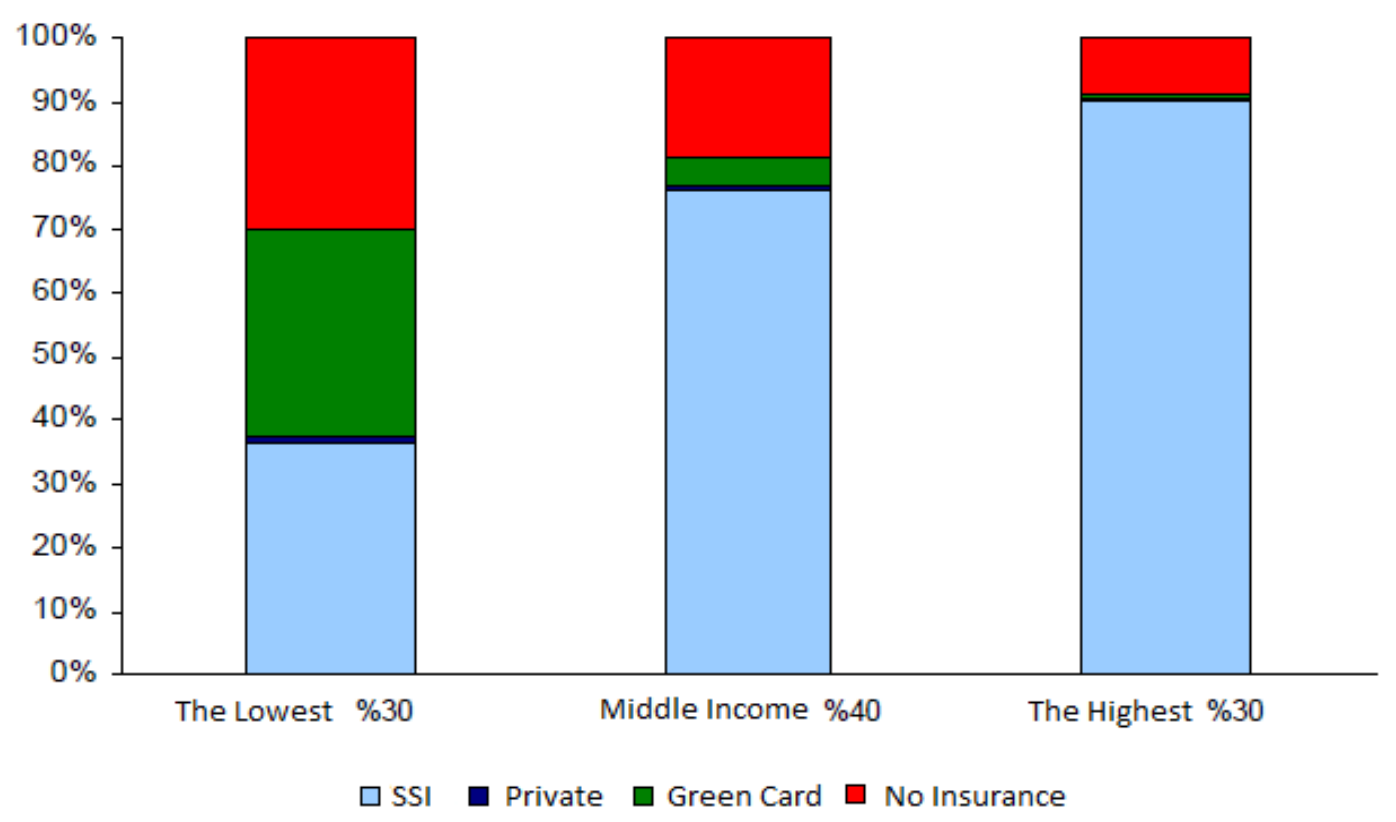

Source: (Gürsel, Darbaz, and Karakoç, 2009: 4).

Graphic 3 suggests data about the distribution of health insurance beneficiaries in different income groups varying from the lowest $\% 30$ to highest $\% 30$. Those who have the lowest income level are the nominee to be green card holders. What motivates people to use green card is their helpless state, in other words, their poverty. In the graphic above, it is clearly comprehended that green card usage diminishes as income goes up. Therefore, those who have the highest level of income find it unnecessary to obtain green card as a health insurance type (Graphic 3).

\footnotetext{
${ }^{2}$ The data in Graphic 3 was prepared based upon OECD household size criteria and household income for each person and it was adapted from Gürsel, Darbaz, and Karakoç Research (2009).
} 


\section{Graphic 4. The Convenience of Green Card Holders Depending Upon Income}

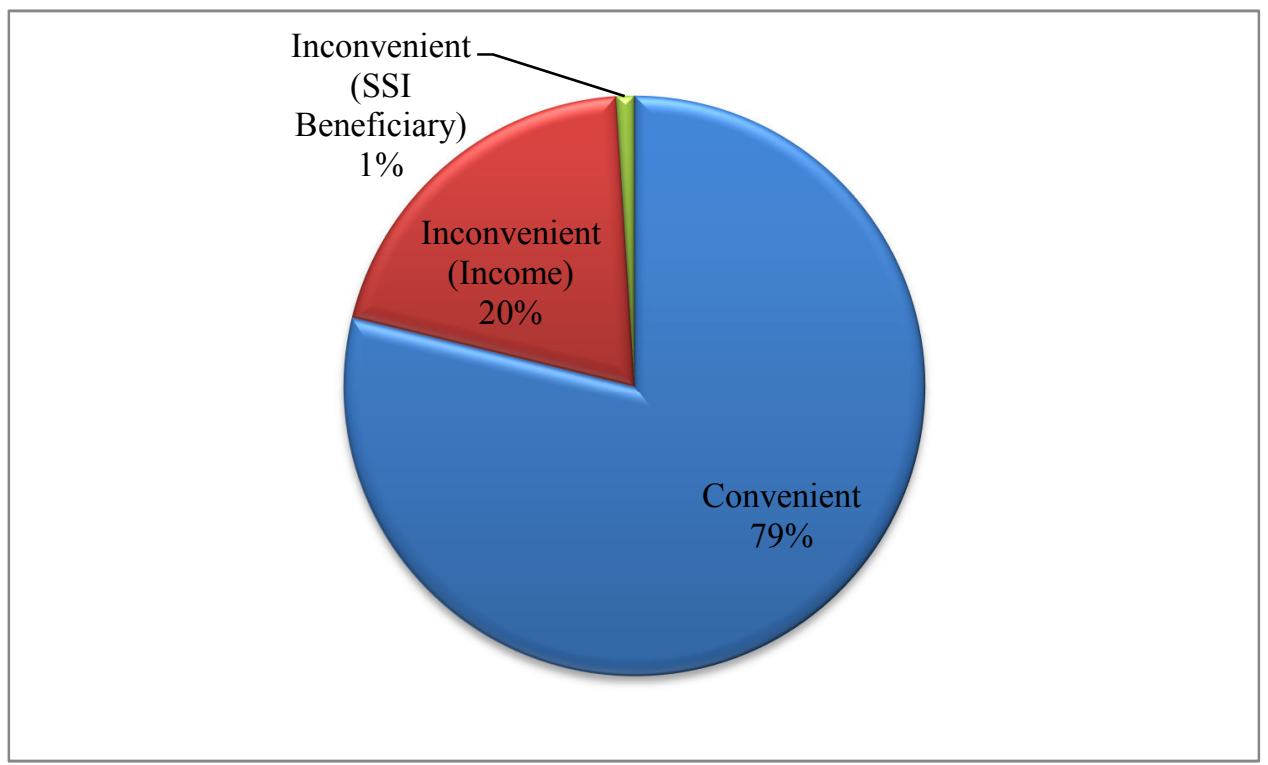

Source: (Gürsel, Darbaz, and Karakoç, 2009: 4).

In graphic 4, the convenience of green card holders depending upon income is demonstrated. Here "convenience" is used to refer to whether green card holders are rightful to possess green cards or not. According to graphic 4, \%79 of green card holders is convenient which means that they are in need of it whereas $\% 20$ of total holders actually is not needy but they have. In a way, they exploit welfare state mechanism and its reflexes. Here in the system, welfare state wishes the goodness or wellbeing of its residents, yet the residents try to exploit it owing to the deficiencies in the welfare state mechanism. This paves the way that settlement of check and balance system is quite significant as the settlement of welfare state apparatuses (Graphic 4).

\section{Concluding Remarks}

Social welfare is the ultimate goal of each state by using mechanisms ranging from social policy instruments to social security and social assistance ideology. Welfare state notion, the purpose of which is to settle the welfare of all, intervenes to economic programs of a particular state, and instead of market economy, state oriented economy is adapted.

Welfare state utilizes different kinds of apparatuses for wellbeing of all from various spheres of life, which sustains equality and prevents social stratification in the social phenomena. Thus, welfare state wages a war against accumulation of capital, on the contrary, capital is to be expanded to the member of the society to sustain equality.

As for social security system as a welfare state mechanism, which was regulated by means of Law No: 5510 in 2006 in Turkey, can be categorized into two: social insurance and social assistance. Social insurance is supported through premiums accumulated compulsorily from insurant who are active employees while social assistance is founded by government and premiums are not mandatory. As a matter of fact, green card health insurance program commenced in 1992 (Law No: 3816) can be categorized within the context of social assistance. The reason is that it supports those "needy" and those whose level of income is below $3 / 1$ of minimum wage in a household. However, later on, green card health insurance 
system converted into the mechanism exploited. Those who are not in need of it have become beneficiary of the system for many years and over 10 million people have begun to get benefit from the system. Consequently, the system was put off and General Health Insurance program was replaced in 2012, January 1. Via General Health Insurance Program income test became compulsory to be beneficiary of the social security services; that is free of charge.

\section{References}

Akyıldız, H. (2012). Sosyal Güvenlik Reformuyla Ulaştı̆̆ Son Şekliyle Sosyal Güvenlik Hukuku, Gözden Geçirilmiş Dördüncü Baskı, Ankara: Alter Yayıncılık.

Alber, J. (1988). "Is There A Crisis of the Welfare State? Cross National Evidence from Europe, North America and Japan", European Sociological Review, 4, 3, 181-207.

Allan, J. P. \& Scruggs, L. (2004). "Political Partisanship and Welfare State Reform in Advanced Industrial Societies", American Journal of Political Science, 48, 3, 496-512.

Alper, Y. (2014). Türk Sosyal Güvenlik Sistemi, Sosyal Sigortalar Hukuku, Güncellemiş 6. Bask1, Bursa: Dora Yayınc1lık.

Andrew, C. (1984). "Women and the Welfare State", Canadian Journal of Political Science, 667-683.

Brady, D. (2005). "The Welfare State and Relative Poverty in Rich Western Democracies", 1967-1997, Social Forces, 83, 4, 1329-1364.

Brady, D., Seeleib-Kaiser, M. \& Beckfield, J. (2005). "Economic Globalization and the Welfare State in Affluent Democracies, 1975-2001", American Sociological Review, 70, 6, 921-948.

Brooks, C. \& Manza, J. (2006). "Why Do Welfare State Persist?”, The Journal of Politics, 68, 4, 816-827.

Corpi, W. (2003). "Welfare State Regress in Western Europea: Politics, Institutions, Globalization, and Europeanization", Annual Review of Sociology, 29, 589-609.

Çolak, M., \& Özer Y. E. (2015). "Sosyal Politika Anlamında Aktif Yaşlanma Politikalarının Ulusal ve Yerel Düzeydeki Analizi”, Elektronik Sosyal Bilimler Dergisi, 14, 55, 115 124.

Dahm, J., Gombert, T., Krell, C., Petring, A. \& Rixen, T. (2012). Welfare State and Social Democracy, Berlin: Friedrich Ebert Stiftung.

"Defending the Welfare State" (1986). The American Political Science Review, 80, 3, 949954.

Diamond, P. A., Lindeman, D. C. \& Young, H. (1996). Social Security What Role for the Future?, Washington, USA: National Academy of Social Insurance.

Freeman, R. B., Topel, R. \& Swedenborg, B. (1997). The Welfare State in Transition: Reforming the Swedish Model, USA: University of Chicago Press.

Garton, S. \& McCallum, M. E. (1996). "Workers' Welfare: Labour and the Welfare State in 20th Century Australia and Canada", Labour History, 71, Australia and Canada, Labour Compared, 116-141.

Gilbert, N. (2004). Transformation of the Welfare State, New York, USA: Oxford University Press. 
Goodin, R. E. (1985). "Vulnerabilities and Responsibilities: An Ethical Defense of the Welfare State", American Political Science Review, 79, 75-787.

Gürsel, S., Darbaz, B. \& Karakoç, U. (2009). "Yeşil Kart: Türkiye'nin En Maliyetli Sosyal Politikasının Güçlü ve Zayıf Yanları”, Bahçeşehir Üniversitesi Ekonomik ve Sosyal Araştırmalar Merkezi (BETAM), Araştırma Notu 09/39, 1-6.

Güzel, A. \& Okur, A. R.., Caniklioğlu, N. (2010). Sosyal Güvenlik Hukuku, 13. Bask1, İstanbul: Beta Yayınlar1,.

Hasenfeld, Y., \& Rafferty, J. A. (1989). "The Determinants of Public Attitudes toward the Welfare State", Social Forces, 67, 4, 1027-1048.

Hoskins, D. (1998). "The Redesign of Social Security", Developments and Trends in Social Security 1996-1998 (Geneva: International Social Security Association, 1998), 1-9.

http://www.merriam-webster.com/dictionary/welfare\%20state (25 December 2015)

http://www.sgk.gov.tr/wps/portal/tr/kurumsal/istatistikler/sgk_istatistik_yilliklari (29 December 2015).

https://www.ttb.org.tr/mevzuat/index (30 December 2015).

Huber, E. \& Stephens, J. D. (2001). Development and Crisis of the Welfare State, Parties and Policies in Global Markets, USA: The University of Chicago Press.

Karadeniz, O. (2007). "Social Security of Casual Agriculture Workers in Turkey", 5th International Research Conference on Social Security, Warsaw, "Social security and the labour market: A mismatch?" International Social Security Association, Research Program, http://www.issa.int/pdf/warsaw07/2karadeniz.pdf (15 January 2016).

Karadeniz, O. (2009). "Turkey Annual National Report Pensions, Health and Long-term Care, Analytical Support on the Socio-Economic Impact of Social Protection Reforms", http://socialprotection.eu/files/353/asisp_ANR09_Turkey.pdf (15 January 2016).

Karadeniz, O. (2012). "Extension of Health Services Coverage Needy in Turkey: From Social Assistance to General Health Insurance”, Sosyal Güvenlik Dergisi, 2, 2, 103-123.

Kaya, M. V. \& Bozkurt, İ. (2011). “İşsizlik, Kişi Başına Milli Gelir (Yoksulluk), Suç Oranı ve Yeşil Kart: 1999-2009 Türkiye Örneği”, Dumlupınar Üniversitesi Sosyal Bilimler Dergisi, 30, 133-140.

Lindback, A. (1995). "Hazardous Welfare-State", The American Economic Review, 85, 2, Papers and Proceedings of the Hundredth and Seventh Annual Meetings of the American Economic Association, Washington DC, 9-15.

Mau, S. \& Veghte, B. (2007). Social Justice, Legitimacy and the Welfare State, USA: Ashgate Publishing Limited.

Oorscot, W. v., Opielka, M., \& Pfau-Effinger, B. (Ed.) (2008), Culture and Welfare State Values and Social Policy in Comparative Perspective, USA: Edward Algar Publishing Limited.

Orhaner, E. (2006). “Türkiye'de Sağlık Hizmetleri Finansmanı ve Genel Sağlık Sigortası”, Ticaret ve Turizm Ĕ̈itim Fakültesi Dergisi, 1, 1-22.

Orloff, A. (1996). "Gender in the Welfare State”, Annual Review of Sociology, 22, 51-78.

Papadakis, E. (1993). "Class Interests, Class Politics, and Welfare State Regime”, The British Journal of Sociology, 44, 2, 249-270. 
Pierson, C. \& Castles, F.G. (2006). The Welfare State Reader, Second Edition, UK: Polity Press Publication.

Risa, A. E. (1995). "The Welfare State as Provider of Accident Insurance in the Workplace: Efficiency and Distribution in Equilibrium", The Economic Journal, 105, 428, 129144.

Social Security Administration, Social Security, Understanding the Benefits, www.socialsecurity.gov.

SSI statistics, available at http://www.sgk.gov.tr/wps/portal/tr/kurumsal/istatistikler/sgk_istatistik_yilliklari (29 December 2015).

Tarcan, M. \& Şahin, İ. (2000), "Hastanelerde Yeşil Kart Uygulamasında Karşılaşılan Sorunlar", Hacettepe Sağllk İdaresi Dergisi, 5, 4, 69-94.

Tatar, M., Mollahaliloğlu, S., Şahin, B., Aydin, S. \& Hernández- QUEVEDO A. M. C. (2011), Turkey: Health system review. Health Systems in Transition,13(6):1-186, http://www.euro.who.int/ en/who-we-are/partners/observatory/health-system-reviewshits/full-list-ofhits/turkey-hit-2011 (05June 2012).

Tuncay, C. \& Ekmekçi, Ö. (2013). Sosyal Güvenlik Hukuku Dersleri, 16. Bask1, İstanbul: Beta Yayıncilık.

TURKSTAT, Health Survey, 2012.

Yüksel, H. (2014). Güncel Gelişmeler Işı̆̆ııda Sosyal Politika, Ekin Yayınevi, Bursa. 